\title{
Sago Bark as Renewable Energy
}

\author{
Chong, K.H. ${ }^{1}$, Law, P.L. ${ }^{2}$, Rigit, A.R.H. ${ }^{3}$, Baini, R. ${ }^{4}$, Shanti, F.S. ${ }^{5}$ \\ Department of Mechanical Engineering, Faculty of Engineering, Universiti Malaysia Sarawak, Malaysia \\ Date Received: $18^{\text {th }}$ March 2014 \\ Date Published: $1^{\text {st }}$ October 2014
}

\begin{abstract}
Much research has been done on the determination of the heating value of biomass waste, but currently no research is being done on the heating value of sago bark. In Malaysia, sago bark is an abundant waste product from sago starch extraction. This study presents the moisture content and heating value determination of paddy straw, empty fruit bunch (EFB), sago bark, oil palm kernel shell (OPKS), and wood chips. The moisture content and heating value of the investigated biomass were determined according to the British Standard EN 1477-2:2009 and bomb calorimeter, accordingly. It was observed that paddy straw recorded the highest moisture content at 97.75\% wt. This was followed by EFB $95.34 \%$ wt., sago bark $96.05 \%$ wt., OPKS $95.28 \%$ wt. and wood chips $11.61 \%$ wt. In the dry state, wood chips had the highest heating value, with a value recorded as approximately $22.41 \mathrm{MJ} \mathrm{kg}^{-1}$, followed by OPKS $21.40 \mathrm{MJ} \mathrm{kg}^{-1}$, sago bark $19.56 \mathrm{MJ} \mathrm{kg}^{-1}$, EFB $17.82 \mathrm{MJ} \mathrm{kg}^{-1}$ and paddy straw $15.33 \mathrm{MJ} \mathrm{kg}^{-1}$. Current experimental trials suggest that the heating value of sago bark makes it suitable for use for co-firing with coal power generation.
\end{abstract}

Keywords: Sago bark, Heating value, Moisture content, Bomb calorimeter, Biomass

\section{INTRODUCTION}

$\mathrm{T}$ HE world oil crisis of the 1970s highlighted concerns over the scarcity of resources [1]. The rapid depletion of the fossil fuel reserve, as well as climate change and the over-dependence on oil, has driven the world to renewable energy sources, which are abundant, untapped and environmentally friendly [2]. Biomass offers important advantages as a combustion feedstock because of the high volatility of the fuel and the high reactivity of both the fuel and the resulting char [3]. Co-firing of biomass residues mitigates greenhouse gases by avoiding $\mathrm{CH}_{4}$ release from the landfilled biomass [4]. In Malaysia, it is estimated that potentially 1340 MW of energy can be generated from biomass by 2030. As of July 2009, there is 39 MW installed capacity under construction under the Biogen Project. The biomass involved is palm oil waste (empty fruit bunch-EFB) and agricultural waste (wood chips, rice husk, etc.) [5].

Currently, Malaysia has huge resources of biomass from the palm oil industries, which contribute $85.5 \%$ of the more than 70 million tons of biomass [6]. The palm oil plantations generate a huge amount of waste, such as chopped trunks, dead fronds, empty fruit bunches, shells and fibres. There were about 4.08 million hectares of palm oil plantations in Malaysia in 2009. In 2009, it was estimated that around 747.20 million tons of empty fruit bunch and oil palm kernel shell (OPKS) were being collected during the pressing of sterilized fruits [7]. Wood waste in Malaysia is mostly found in the logging industries. The total land area in Malaysia is 32.98 million hectares. In 2009, the total production of logs based on the total land area was 18.27 million $\mathrm{m}^{3}$ [8]. In March 2005, the Cabinet tasked the Ministry of Plantation Industries and Commodities to pursue an aggressive program for the development of forest plantation in Malaysia. Under this program, the Ministry has planned to develop 375,000 hectares of forest plantation at an annual planting rate of 25,000 hectares per year for the next 15 years. Once successfully implemented, every 25,000 hectares of land planted is expected to produce 5 million cubic meters of timber [9]. Therefore, this program will increase the quantity of wood residue every year, which can be used for bioenergy. In Malaysia, rice is the main food crop and is grown on small farms. According to Wong and his team, there was an increase in rice production from 2004 to 2009 of about 7.88\% [10]. Due to the demand for rice, the paddy plantation area and yield of paddy per hectare has also increased consistently every year. In some countries, paddy straw is used for cofiring with coal power generation [11], [12].

This work was supported in part by ANPCYT.

1 Student, Department of Mechanical Engineering, Faculty of Engineering, Universiti Malaysia Sarawak, Malaysia (60109836674; isaackokhing@gmail.com)

2 Lecturer, Department of Civil Engineering, Faculty of Engineering, Universiti Malaysia Sarawak, Malaysia (puonglaw@feng.unimas.my).

3 Lecturer, Department of Mechanical Engineering, Faculty of Engineering, Universiti Malaysia Sarawak, Malaysia (arigit@ feng.unimas.my).

4 Lecturer, Department of Chemical Engineering and Energy Sustainability, Faculty of Engineering, Universiti Malaysia Sarawak, Malaysia, (ruby@feng.unimas.my).

5 Lecturer, Department of Chemical Engineering and Energy Sustainability, Faculty of Engineering, Universiti Malaysia Sarawak, Malaysia (sshanti@feng.unimas.my). 
In Malaysia, approximately $90 \%$ of the sago starch is produced from the State of Sarawak. Recent development in sago starch research leads to a total of over 60,000 hectares being cultivated with sago palm [13]. Daily sago starch production is about 24 tons or equivalent to $20 \mathrm{~kg}(15 \%)$ of starch/log [14]. In modern sago starch extraction, 0.5 tons of sago bark waste are produced per ton of dried flour [15]. Normally, the bark is not fully utilized for higher value added products and, until now, there has been no clear new technology that can be adapted for alternative sago bark utilization.

Corder [16] and Kelsey [17] conducted extensive research on the heating values of coniferous and non-coniferous species but did not include sago bark in their analysis. This paper aims to contribute the knowledge of sago bark's heating value and compare it with other abundant biomass wastes in Malaysia. This will help to examine the possibility of using sago bark as renewable energy in Malaysia. Table 1 shows the typical proximate and ultimate analysis of empty fruit bunch (EFB), oil palm shell (OPKS), wood chips and paddy straw.

Table 1: Typical proximate and ultimate analysis of EFB, OPKS, wood chips and paddy straw

\begin{tabular}{|l|l|l|l|l|}
\hline & EFB & OPKS & $\begin{array}{l}\text { Wood } \\
\text { chips }\end{array}$ & $\begin{array}{l}\text { Paddy } \\
\text { straw }\end{array}$ \\
\hline $\begin{array}{l}\text { Proximate analysis (\% } \\
\text { wt. dry basis) }\end{array}$ & & & & \\
\hline Volatile matter & 67.50 & 72.47 & 77.30 & 74.70 \\
\hline Fixed carbon & 27.90 & 18.56 & 19.40 & 15.20 \\
\hline Ash & 4.60 & 8.97 & 3.40 & 10.10 \\
\hline $\begin{array}{l}\text { Ultimate analysis (\% wt. } \\
\text { dry basis) }\end{array}$ & & & & \\
\hline Carbon & 40.70 & 51.63 & 50.80 & 45.20 \\
\hline Hydrogen & 5.40 & 5.52 & 6.40 & 6.50 \\
\hline Nitrogen & 0.30 & 1.89 & 0.40 & 0.80 \\
\hline Sulphur & 1.20 & 0.05 & & \\
\hline Oxygen (by different) & 47.80 & 40.91 & 37.90 & 47.50 \\
\hline $\begin{array}{l}\text { Higher heating value } \\
\text { (HHV) (MJ/kg) }\end{array}$ & 19.30 & 22.97 & 18.00 & 16.28 \\
\hline Reference & {$[18]$} & {$[19]$} & {$[20]$,} & {$[22]$,} \\
& & & {$[21]$} & {$[23]$} \\
\hline
\end{tabular}

\section{MATERIAL AND METHODS}

\section{A. Moisture Content}

Determination of the moisture content of the samples was conducted in the Chemical Engineering Analytical Lab (UNIMAS) according to the British Standard EN 1477-2:2009 [24] using a Binder drying oven with natural convection (Figure 1). The size of the investigated sample was ground to $(1.0 \pm 0.1) \mathrm{mm}$, and the weight at all times was about $200 \mathrm{~g}$.

First, an empty clean drying container was weighed to the nearest $0.1 \mathrm{~g}$. The sample investigated was transferred to the drying container. Then, the drying container with the sample is weighed to the nearest $0.1 \mathrm{~g}$. The drying container with the sample was dried in the Binder drying oven with convection controlled at $(100 \pm 0.5)^{\circ} \mathrm{C}$ and weighed before and after drying. Finally, the drying container with the sample was heated until constancy in mass is achieved. Constancy in mass is defined as a change not exceeding $0.2 \%$ of the total loss in mass during a further period of heating at $(100 \pm 0.5)^{\circ} \mathrm{C}$ over a period of 60 $\min$.

The moisture content, $\mathrm{M}_{\mathrm{ar}}$, of the investigated sample as received is expressed as $\%$ of total mass using (1). The result is reported on a wet basis.

$$
M_{a r}=\left[\left(m_{2}-m_{3}\right)+m_{4} /\left(m_{2}-m_{1}\right)\right] * 100
$$

where $M_{a r}$ is the moisture content in the sample as received, $m_{l} \quad$ is the mass in $\mathrm{g}$ of the empty drying container, $m_{2}$ is the mass in $\mathrm{g}$ of the drying container and sample before drying, $m_{3}$ is the mass in $\mathrm{g}$ of the drying container and sample after drying, and $m_{4}$ is the mass in $\mathrm{g}$ of the moisture associated with the packing.

The results are calculated to two decimal places and rounded to the nearest $0.1 \%$ for reporting. There are three repetitions of this procedure from the collected bulk sample and result are reported as an average. 


\section{UNIMAS e-Journal of Civil Engineering}

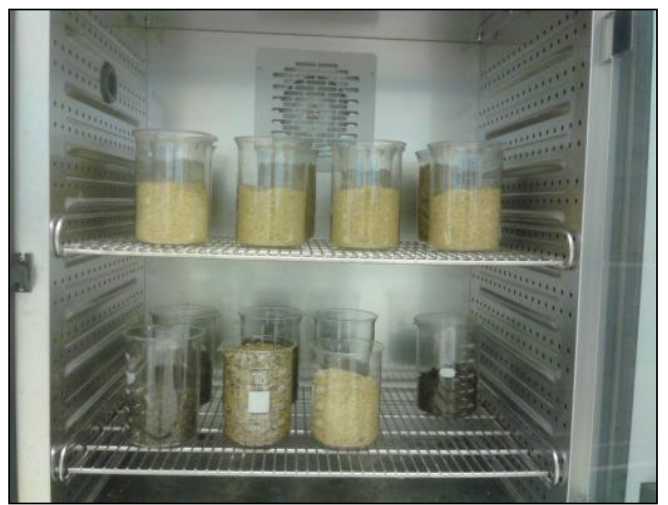

Figure 1: Binder drying oven with natural convection

\section{B. Heating Values}

An estimated $10 \mathrm{~kg}$ of paddy straw and wood chips were collected at Kota Samarahan; $10 \mathrm{~kg}$ of sago bark was collected at $\mathrm{Bau} ; 10 \mathrm{~kg}$ of EFB and OPKS were collected at Serian. In this research, a Sanyo Gallenkamp bomb calorimeter was used to determine the heating value of the solid samples according to (2) on a wet basis (Figure 2). All the biomass samples were blended and weighed at approximately $1.0 \mathrm{~g}$ each and then were pelletized with a Gallenkamp briquette presser. The pelletized samples were put in the ignition cup, with wire wrapped around the ends of the electrode terminals. A cord was bent into good contact with the compacted pellet sample but without touching the ignition cup. The outlet valve on the bomb was closed and $30 \%$ of atmosphere of oxygen was injected into the bomb. The bucket was placed into the insulating jacket. A total of 2 litres of water was introduced into the holding bucket. The lead wires were attached to the bomb while the bomb was placed above the water. The bomb was lowered gently into the bucket. A thermometer was lowered into the calorimeter. The fired bottom was pressed simultaneously with time keeping, and then the initial temperature was observed for several minutes until equilibrium was reached. The evaluated temperature and time were taken every minute until equilibrium was obtained. For each test to determine the heating value and moisture content, all the readings in this experiment were taken three times for repeatability and the average of these readings was taken for final analysis.

$$
\text { Heating value }=C_{\text {apparatus }} *(\Delta T) / M_{f}
$$

where $C_{\text {apparatus }}$ is the heat capacity of apparatus $(\mathrm{J} / \mathrm{K}), \Delta T$ is the temperature rise $(\mathrm{K})$, and $M_{f}$ is the mass of fuel sample (kg).

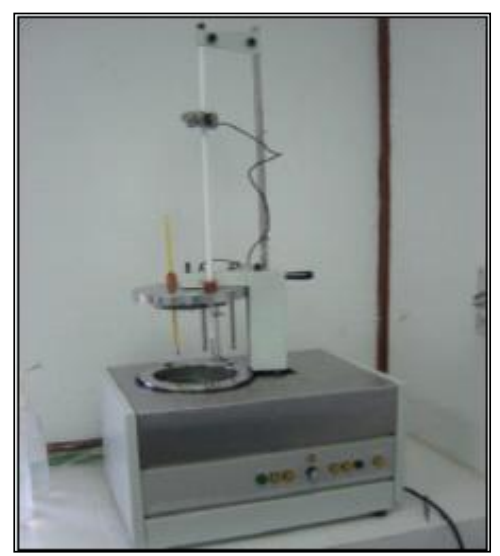

Figure 2: Bomb calorimeter

\section{RESULTS AND DISCUSSION}

\section{A. Moisture Content}

A comparison of the moisture content of the as received collected biomass is shown in Figure 3. Paddy straw recorded the highest moisture content as $97.75 \%$ wt. This was followed by EFB 95.34\% wt., sago bark 96.05\% wt., OPKS 95.28\% wt. and wood chips $11.61 \%$ wt. The moisture content of the biomass can vary significantly from $20-60 \%$ due to local and seasonal weather [25], [26].

Information of biomass moisture content can assist in combustion efficiency and pollutant control. Biswas et al. [27] discovered wet biomass fuel (moisture content: 12\%) required longer combustion time compare to dried biomass fuel 
(moisture content: close to 1\%). Moisture content of biomass are found inversely proportion to ignition front temperature, process temperature, ignition front velocity, equivalence fuel/air ratio, and overall burning rate [28]. The increase of biomass moisture content will retards the hydroxyl radical $\left(\mathrm{OH}^{*}\right)$ and methylidyne radical $\left(\mathrm{CH}^{*}\right)$ emissions and decreases the maximum values of these emissions [29]. Liang et al. [30] found that the average concentration of carbon monoxide (CO) and carbon dioxide $\left(\mathrm{CO}_{2}\right)$ inversely proportion to the moisture content level of biomass. Moisture content of biomass also have effect on lowers ash deposition rate and reduce chlorine deposition. Shao et al. [31] identified the combustion of relatively wet solid fuels lowered ash deposition rate and reduced chlorine deposition. In addition, moisture content also play a significant role in the increase of pellet density [32].

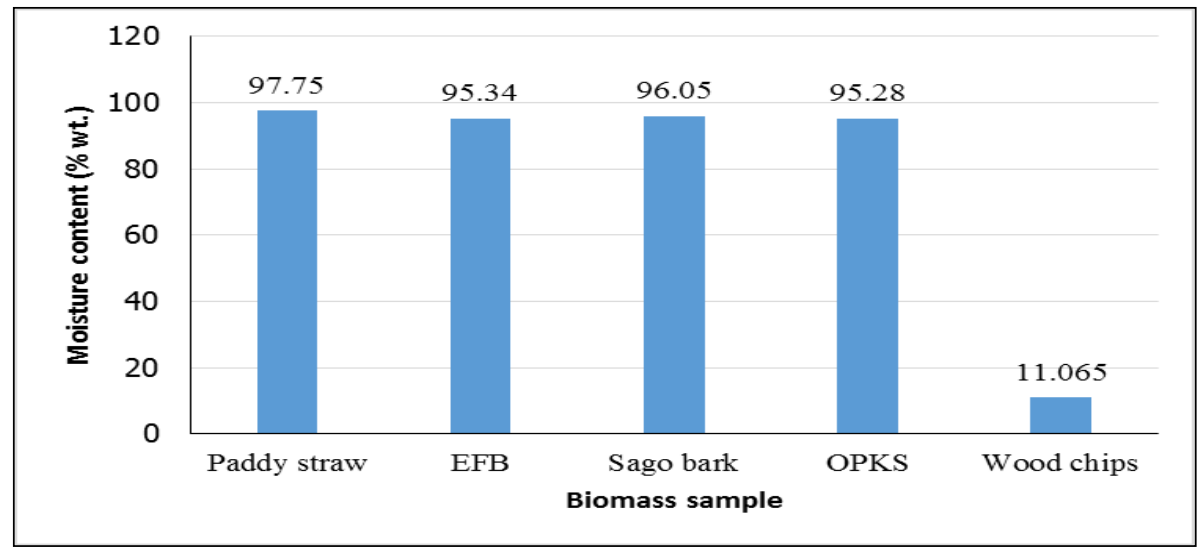

Figure 3: Moisture content of investigated biomass samples

\section{B. Heating Values}

Table 2 and Figure 4 show the heating values of paddy straw, EFB, sago bark, OPKS and wood chips. In their natural state, wood chips had the highest heating value, with a value recorded as approximately $18.05 \mathrm{MJ} \mathrm{kg}^{-1}$, followed by OPKS 17.13 $\mathrm{MJ} \mathrm{kg}^{-1}$, EFB $10.89 \mathrm{MJ} \mathrm{kg}^{-1}$, sago bark $10.63 \mathrm{MJ} \mathrm{kg}^{-1}$ and paddy straw $5.43 \mathrm{MJ} \mathrm{kg}^{-1}$. In the dry state, wood chips had the highest heating value, with a value recorded as approximately $22.41 \mathrm{MJ} \mathrm{kg}^{-1}$, followed by OPKS $21.40 \mathrm{MJ} \mathrm{kg}^{-1}$, sago bark $19.56 \mathrm{MJ} \mathrm{kg}^{-1}$, EFB $17.82 \mathrm{MJ} \mathrm{kg}^{-1}$ and paddy straw $15.33 \mathrm{MJ} \mathrm{kg}^{-1}$.

Generally the determined dry state heating values of the investigated samples are close to those in the work of other researchers [18]-[20], [23]. Factors that affect the heating value are species, wood density, and moisture content [33]. The heating values of OPKS and wood chips are higher than sago bark. Generally, OPKS is utilized as a fuel to generate steam and electricity in the palm processing mill itself [11],[12]. Wood chips generated are used as fuel and fertilizer [36]. Although the heating values of paddy straw and EFB are lower than sago bark, both are generally used for co-firing with coal power generation [12], [37]. In view of the underutilized resource of sago bark in Malaysia, it has great potential to be used as a fuel in co-firing with coal power generation.

Table 2: Heating values of paddy straw, empty fruit bunch, oil palm kernel shell, sago bark and wood chips

\begin{tabular}{|l|c|c|c|c|c|}
\hline Sample & Paddy straw & EFB & Sago bark & OPKS & Wood chips \\
\hline Natural state (MJ/kg) & 5.43 & 10.89 & 10.63 & 17.13 & 18.05 \\
\hline Dry state (MJ/kg) & 15.33 & 17.82 & 19.56 & 21.40 & 22.41 \\
\hline References dry state & 16.28 & 19.30 & & 22.97 & 18.00 \\
(MJ/kg) & {$[23]$} & {$[18]$} & & {$[19]$} & {$[20]$} \\
\hline
\end{tabular}




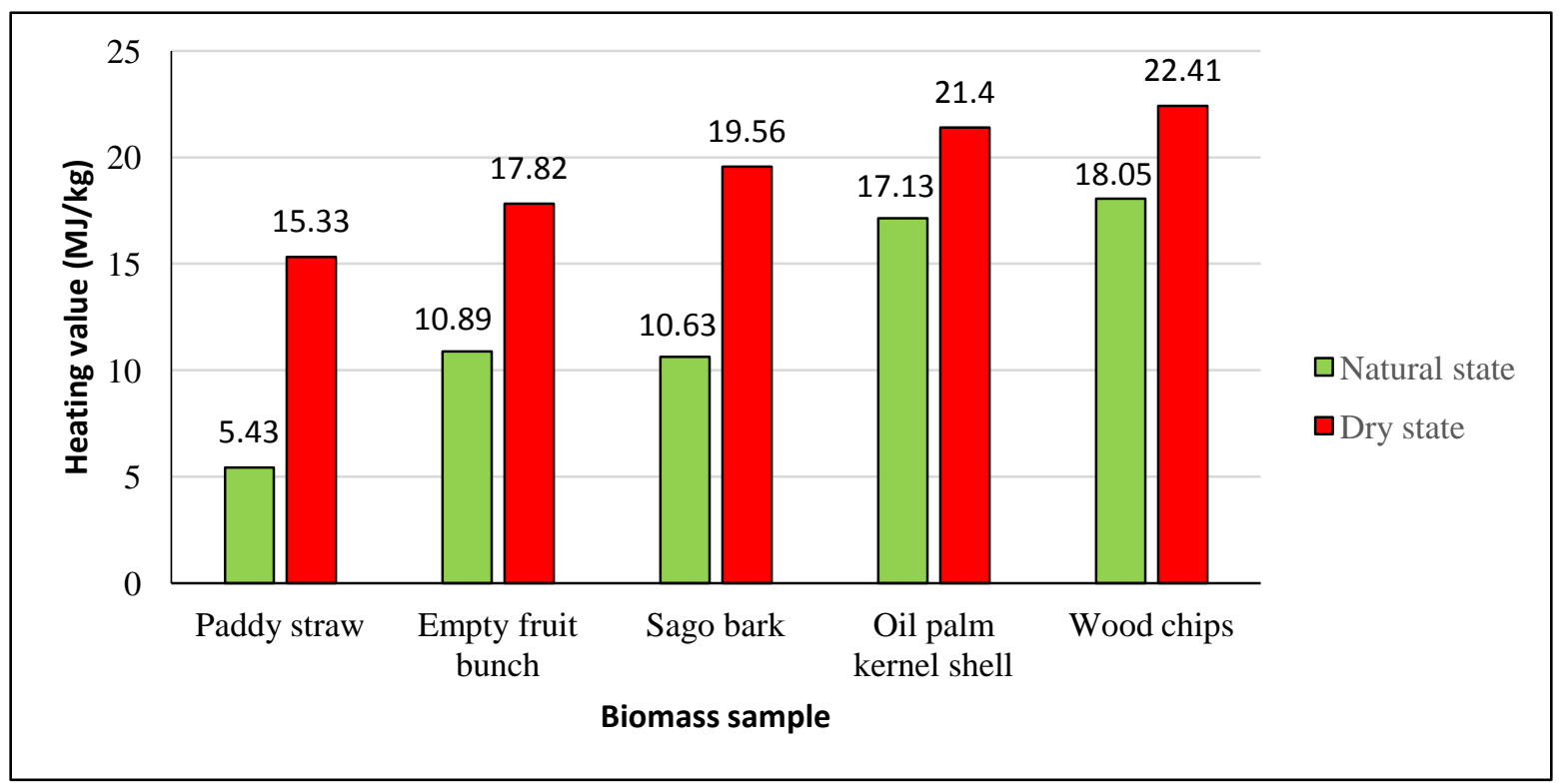

Figure 4: Heating values of paddy straw, EFB, sago bark, OPKS and wood chips

\section{CONCLUSIONS}

This study presents the determination of the moisture content and heating values of paddy straw, empty fruit bunch, sago bark, oil palm kernel shell and wood chips. The following conclusions can be drawn from the results:

(1) Paddy straw recorded the highest moisture content as $97.75 \%$ wt. This was followed by EFB 95.34\% wt., sago bark $96.05 \%$ wt., OPKS $95.28 \%$ wt. and wood chips $11.61 \%$ wt.

(2) In their natural state, wood chips had the highest heating value, with a value recorded as approximately $18.05 \mathrm{MJ}$ $\mathrm{kg}^{-1}$, followed by OPKS $17.13 \mathrm{MJ} \mathrm{kg}^{-1}$, EFB $10.89 \mathrm{MJ} \mathrm{kg}^{-1}$, sago bark $10.63 \mathrm{MJ} \mathrm{kg}^{-1}$ and paddy straw $5.43 \mathrm{MJ} \mathrm{kg}^{-1}$.

(3) In their dry state, wood chips had the highest heating value, with a value recorded as approximately $22.41 \mathrm{MJ} \mathrm{kg}^{-1}$, followed by OPKS 21.40 MJ kg-1, sago bark $19.56 \mathrm{MJ} \mathrm{kg}^{-1}$, EFB $17.82 \mathrm{MJ} \mathrm{kg}^{-1}$ and paddy straw $15.33 \mathrm{MJ} \mathrm{kg}^{-1}$.

Current experimental trials suggest that the heating value of sago bark makes it suitable for use as a fuel in co-firing with coal power generation.

\section{ACKNOWLEDGMENT}

The authors acknowledge the financial support provided by Prima Natural Resources and Manufacturing Sdn. Bhd. and Zamalah Siswazah UNIMAS. They also acknowledge the help provided by technicians from the Faculty of Resource Science \& Technology, UNIMAS.

\section{REFERENCES}

[1] A. S. Jum'ah, H. Lund, and C. Mandill, "The New Energy Security Paradigm,” 2006. [Online]. Available: http://www.weforum.org/pdf/Energy.pdf

[2] T. H. Oh, S. Y. Pang, and S. C. Chua, "Energy policy and alternative energy in Malaysia: Issues and challenges for sustainable growth," Renew. Sustain. Energy Rev., vol. 14, no. 4, pp. 1241-1252, May 2010.

[3] A. Demirbas, "Potential applications of renewable energy sources, biomass combustion problems in boiler power systems and combustion related environmental issues," Prog. Energy Combust. Sci., vol. 31, no. 2, pp. 171-192, 2005.

[4] M. Sami, K. Annamalai, and M. Wooldridge, "Co-firing of coal and biomass fuel blends," Prog. Energy Combust. Sci., vol. 27, no. 2, pp. 171-214, Jan. 2001.

[5] A. H. Haris, "Introduction \& the Malaysian feed-in tariff scenario," Kuala Lumpur, 2010. [Online]. Available: http://www.bioenergynet.com/articles/technology/biomass/251-significant-biomass-properties-part-1-moisture-content.

[6] S. H. Shuit, K. T. Tan, K. T. Lee, and a. H. Kamaruddin, "Oil palm biomass as a sustainable energy source: A Malaysian case study," Energy, vol. 34, no. 9 , pp. $1225-1235$, Sep. 2009.

[7] MPOB, "Malaysian oil palm statistics 2009." 2009.

[8] MTC, "Malaysia: Forestry \& environment (facts \& figures)," MTC, 01 -May-2009. [Online]. Available: http://forestry.oupjournals.org/cgi/doi/10.1093/forestry/74.5.499.

[9] MTCC, "review of malaysian criteria and indicators for forest management certification (Forest plantations) MTCC," 2013. [Online]. Available: http://www.mtcc.com.my/activities/review-of-malaysian-criteria-and-indicators-for-forest-management-certification-forest-plantations.

[10] K. K. Wong, C. K. Lee, K. S. Low, and M. J. Haron, "Removal of $\mathrm{Cu}$ and $\mathrm{Pb}$ by tartaric acid modified rice husk from aqueous solutions," Chemosphere, vol. 50, no. 1, pp. 23-28, Jan. 2003.

[11] S. M. Shafie, T. M. I. Mahlia, and H. H. Masjuki, "Life cycle assessment of rice straw co-firing with coal power generation in Malaysia," Energy, vol. 57, no. 0, pp. 284-294, Aug. 2013.

[12] B. M. Jenkins and A. P. Bhatnagar, "On the electric power potential from paddy straw in the Punjab and the optimal size of the power generation station," Bioresour. Technol., vol. 37, no. 1, pp. 35-41, 1991.

[13] DOSM, "Monthly Statistical Bulletin," Kuching, 2002.

[14] K. B. Bujang, K. Apun, and M. A. Salleh, "A study in the production and bioconversion of sago waste," in Proceeding of the 6th International Sago Symposium, Sago: The Future Source of Food and Feed, 1996, pp. 193-200. 


\section{UNIMAS e-Journal of Civil Engineering}

[15] Praytno, "Palm Wood Utilization: Sago Properties and it Utilization," University of Yogyakarta, 1991.

[16] S. E. Corder, "Properties and Uses of Bark as an Energy Source," Oregon, 1976.

[17] R. G. Kelsey, F. Shafizadeh, and D. P. Lowery, "Heat Content of Bark, Twigs, and Foliage of Nine Species of Western Conifers," 1979

[18] S. Konsomboon, S. Pipatmanomai, T. Madhiyanon, and S. Tia, "Effect of kaolin addition on ash characteristics of palm empty fruit bunch (EFB) upon combustion," Appl. Energy, vol. 88, no. 1, pp. 298-305, Jan. 2011.

[19] W. a. Wan Ab Karim Ghani, R. A. Moghadam, M. a. M. Salleh, and a. B. Alias, "Air Gasification of Agricultural Waste in a Fluidized Bed Gasifier: Hydrogen Production Performance," Energies, vol. 2, no. 2, pp. 258-268, May 2009.

[20] R. A. Arola, "Wood fuels - how do they stack up?," in Energy and the Wood Products Industry, 1976, pp. 34-35.

[21] J. Brammer and A. Bridgwater, "Drying technologies for an integrated gasification bio-energy plant," Renew. Sustain. energy Rev., vol. 3 , 1999.

[22] J. Wannapeera, "Product yields and characteristics of rice husk, rice straw and corncob during fast pyrolysis in a drop-tube/fixed-bed reactor," Songklanakarin J. Sci. Technol., vol. 30, no. 3, pp. 393-404, 2008.

[23] B. M. Jenkins and J. M. Ebeling, "Thermochemical properties of biomass fuels," California agriculture, May-June 1985, no. June, pp. 14-16, 1985.

[24] BSI, "BS EN 14774-2:2009: Solid biofuels - Determination of moisture content - oven dry method. Part 2: Total moisture - simplified method," BS EN 14774-2:2009, 2009.

[25] D. C. Markstrom, H. E. Worth, and T. Garbutt, Size and moisture content of pulp chips from living and dead Englemann spruce and subalpine fir United States: Dept. of Agriculture, 1977, pp. 1-4.

[26] BioenergyNet, "Significant biomass properties. Part 1: Moisture content," $2014 . \quad$ [Online]. Available: http://www.bioenergynet.com/articles/technology/biomass/251-significant-biomass-properties-part-1-moisture-content.

[27] A. K. Biswas, M. Rudolfsson, M. Broström, and K. Umeki, "Effect of pelletizing conditions on combustion behaviour of single wood pellet," Appl. Energy, vol. 119, pp. 79-84, Apr. 2014.

[28] J. F. Pérez, A. Melgar, and P. N. Benjumea, "Effect of operating and design parameters on the gasification/combustion process of waste biomass in fixed bed downdraft reactors: An experimental study," Fuel, vol. 96, pp. 487-496, Jun. 2012.

[29] F. V Tinaut, A. Melgar, B. Giménez, and M. Reyes, "Characterization of the combustion of biomass producer gas in a constant volume combustion bomb," Fuel, vol. 89, no. 3, pp. 724-731, Mar. 2010.

[30] L. Liang, R. Sun, J. Fei, S. Wu, X. Liu, K. Dai, and N. Yao, "Experimental study on effects of moisture content on combustion characteristics of simulated municipal solid wastes in a fixed bed," Bioresour. Technol., vol. 99, no. 15, pp. 7238-7246, Oct. 2008

[31] Y. Shao, C. (Charles) Xu, J. Zhu, F. Preto, J. Wang, G. Tourigny, C. Badour, and H. Li, "Ash and chlorine deposition during co-combustion of lignite and a chlorine-rich Canadian peat in a fluidized bed - Effects of blending ratio, moisture content and sulfur addition," Fuel, vol. 95, no. 0, pp. 25-34, May 2012.

[32] A. K. Biswas, M. Rudolfsson, M. Broström, and K. Umeki, "Effect of pelletizing conditions on combustion behaviour of single wood pellet," Appl. Energy, vol. 119, no. 0, pp. 79-84, Apr. 2014.

[33] W. Rolls, "Wood as fuel." Crown, pp. 1-6, 2011

[34] O. Chavalparit, W. H. Rulkens, a. P. J. Mol, and S. Khaodhair, "Options for Environmental Sustainability of the Crude Palm Oil Industry in Thailand Through Enhancement of Industrial Ecosystems," Environ. Dev. Sustain., vol. 8, no. 2, pp. 271-287, Mar. 2006

[35] A. B. Nasrin, A. N. Ma, Y. M. Choo, S. Mohamad, M. H. Rohaya, A. Azali, and Z. Zainal, "Oil Palm Biomass As Potential Substitution Raw Materials For Commercial Biomass Briquettes Production,” Am. J. Appl. Sci., vol. 5, no. 3, pp. 179-183, 2008.

[36] S. Hashimoto, Y. Moriguchi, A. Saito, and T. Ono, "Six indicators of material cycles for describing society's metabolism: application to wood resources in Japan," Resour. Conserv. Recycl., vol. 40, no. 3, pp. 201-223, Feb. 2004.

[37] S. M. Shafie, T. M. I. Mahlia, and H. H. Masjuki, "Life cycle assessment of rice straw co-firing with coal power generation in Malaysia," Energy, vol. 57, pp. 284-294, Aug. 2013. 